\title{
Uji Aktivitas Antibakteri Ekstrak Etanolik Kayu Secang (Caesalpinia sappan L.) terhadap Staphylococcus aureus
}

\author{
Antibacterial Activity Test of Secang Wood (Caesalpinia sappan L.) \\ Ethanolic Extract against Staphylococcus aureus
}

\author{
Diah Mukti Cahyaningtyas ${ }^{1}$, Nony Puspawati ${ }^{1}$ dan Rinda Binugraheni*2 \\ ${ }^{1}$ Program Studi D4 Analis Kesehatan \\ ${ }^{2}$ Program Studi D3 Analis Kesehatan \\ Fakultas Ilmu Kesehatan, Universitas Setia Budi Surakarta, \\ Jl. Let. Jend. Sutoyo, Mojosongo, Surakarta, 57127, Jawa Tengah, Indonesia \\ *Corresponding author: rinda.binugraheni@gmail.com
}

Received: Agustus 24, 2019; Revise: October 23., 2019; Accepted: November 8, 2019

DOI : https://doi.org/10.31001/biomedika.v12i2.614

\begin{abstract}
ABSTRAK
Infeksi piogenik merupakan infeksi yang ditandai dengan terjadinya peradangan lokal yang parah disertai nanah (pus) dan umumnya disebabkan oleh kuman piogenik, salah satu yang paling umum adalah Staphylococcus aureus. Salah satu tanaman yang banyak dimanfaatkan sebagai bahan obat tradisional dan sebagai antibakteri adalah tanaman secang. Penelitian ini bertujuan untuk mengetahui aktivitas antibakteri ekstrak etanolik kayu secang (Caesalpinia sappan L.) terhadap Staphylococcus aureusisolat laboratorium dan isolat pus pasien dan mengetahui perbedaan daya hambat antara kedua bakteri tersebut. Serbuk kayu secang sebanyak 300 gram diekstraksi dengan metode maserasi menggunakan pelarut etanol 70\% (1:10). Maserat digunakan untuk uji aktivitas antibakteri terhadap Staphylococcus aureusisolat laboratorium dan isolat pus pasien Rumah Sakit menggunakan metode difusi dan dilusi. Hasil uji difusi kemudian dianalisis menggunakan uji Anova dua arah.Hasil penelitian menunjukkan ekstrak etanolik kayu secang mempunyai aktivitas antibakteri. Hasil metode dilusi menunjukkan nilai KBM pada konsentrasi 3\% untuk Staphylococcus aureusisolat laboratorium dan konsentrasi $4 \%$ untuk Staphylococcus aureus isolat pus pasien. Analisis statistik hasil uji difusi menunjukkan konsentrasi paling baik dalam menghambat pertumbuhan kedua bakteri tersebut adalah konsentrasi $25 \%$ dan kesensitifan Staphylococcus aureusisolat laboratorium dan isolat pus pasien terhadap ekstrak adalah sama.

Kata kunci: antibakteri; ekstrak etanolik kayu secang;Staphylococcus aureus
\end{abstract}

\section{ABSTRACT}

Piogenic infection is an infection characterized by the occurrence of severe local inflammation with pus formation (pus). Generally caused by piogenic germs, one of the most common is Staphylococcus aureus. One of the plants used as an ingredient in traditional medicine and used as an anti-bacterial is a secang plant. This study aims to determine the anti-bacterial activity of ethanolic extract of secang wood (Caesalpinia sappan L.) on pure cultivation Staphylococcus aureus Laboratory and isolates pus Hospital patients and find out the difference in inhibition between the two bacterias.300 grams of secang wood powder was extracted by maceration method using 70\% ethanol (1:10). Maserate was used to test the anti-bacterial activity of Staphylococcus aureus from pure cultivation laboratory and isolates of pus patients in hospital using diffusion and dilution methods. Then, the results of the diffusion test were analyzed using a two-way Anova test.The results of the study showed that ethanolic extracts of wood have anti-bacterial activity. Result of dilution method showed the value of KBM at a concentration of 3\% for Staphylococcus aureus cultivation Laboratory and a concentration of $4 \%$ for Staphylococcus aureus isolates pus patients of the Hospital. The statistical analysis of diffusion test results showed that the best concentration in inhibiting the growth of these two bacterias were the concentration of $25 \%$ and the sensitivity of Staphylococcus aureus from Laboratory pure cultivation and the Pus patients isolate of the Hospital toward extracts were the same.

Key word:anti-bacterial; ethanolic extract of secang wood; Staphylococcus aureus 


\section{PENDAHULUAN}

Infeksi piogenik ditandai dengan terjadinya peradangan lokal yang parah dan pembentukan nanah (pus). Infeksi ini umumnya disebabkan oleh salah satu kuman piogenik. Kuman piogenik yang paling umum adalah Staphylococcus epidermidis, Staphylococcus aureus, Streptococcus pyogenes, Streptococcus pneumonia, Escherichia coli, Klebsiella pneumonia, Pseudomonas aeruginosa, Neisseria gonorrhoeae, Salmonella typhi, Mycobacterium tuberculosis (Singh et al., 2013).

Infeksi piogenik salah satu penyebab adalah bakteri Staphylococcus aureus. Bakteri ini paling sering menyebabkan sakit pada kulit dan jaringan superfisial, seperti luka bakar, pustule, koreng, abses, dan infeksi karena kecelakaan dan infeksi sesudah menjalani operasi. Staphylococcus aureus dalam jumlah kecil merupakan flora normal pada kulit, tenggorokan, mulut, dan hidung manusia (Iskamto, 2009).

Berdasarkan hasil penelitian Nurmala et al (2015), didapatkan bahwa terdapat 21 jenis bakteri dari seluruh sampel yang Pus diperiksa dan diantaranya didapatkan Staphylococcus aureus (0,9\%). Resistensi terjadi pada bakteri-bakteri yang ditemukan pada spesimen pus tersebut terhadap 40 jenis antibiotik dari 46 antibiotik yang diperiksa. Sampel pus tersebut berasal RSU dr. Soedarso Pontianak yang diperiksa di Unit Laboratorium Kesehatan Provinsi Kalimantan Barat tahun 2011-2013.

Bahaya resistensi antibiotik saat ini telah menjadi masalah kesehatan dunia yang serius.Antibiotik biasanya digunakan untuk mengobati penyakit infeksi yang disebabkan oleh Staphylococcus aureusnamun pada beberapa kasus telah ditemukan beberapa strain Staphylococcus aureus yang resisten terhadap antibiotik seperti

Methicillin-Resistan

Staphylococcus areus (MRSA). Di Indonesia pada tahun 2010 proporsi MRSA diperkirakan 28\% (Chen dan Huang, 2014). Pemanfaatan bahan alami dapat digunakan sebagai alternatif pengobatan tradisional, salah satunya yaitu menggunakan tanaman obat (Artanti dan Fatimah, 2017).

Indonesia merupakan negara yang kaya akan berbagai jenis tanaman yang dapat dimanfaatkan sebagai bahan obatobatan, diantaranya sebagai obat tradisional, herbal dan jamu. Salah satu tanaman yang banyak dimanfaatkan sebagai bahan obat tradisional adalah tanaman secang. Bagian tanaman secang (Caesalpinia sappan L.) yang sering dimanfaatkan sebagai bahan obat tradisional adalah kayu dalam potonganpotongan atau serutan kayu. Kayu secang sebagai minuman herbal digunakan untuk antimikroba, pengobatan darah kotor, antitumor, antivirus, antikoagulan, antidiabetik, dan sebagai antiinflamasi (Kusuma, 2007). Berdasarkan penelitian Sa'diah et al (2013), ekstrak secang yang berasal dari Semarang setelah diformulasi menjadi krim efektif sebagai obat anti jerawat yang disebabkan oleh bakteri Propionibacterium acnes.

Berdasarkan penelitian Kusmiati et al (2014), hasil analisis kandungan senyawa kimia ekstrak kayu secang (Caesalpinia sappan L.) menggunakan Kromatografi Gas-Spektrofotometri Massa (KG-SM) menunjukkan bahwa ekstrak kayu secang mengandung senyawa fenol dan asam lemak yang bersifat sebagai 
antibakteri. Hasil penelitian Kumala et al. (2009) menunjukkan bahwa air rebusan kayu secang mampu menurunkan jumlah koloni pada cairan intraperitonium mencit yang diinfeksi Escherichia coli.

Berdasarkan penelitian-penelitian yang terdahulu, sudah banyak dilakukan penelitian mengenai khasiat Ekstrak kayu secang (Caesalpinia sappan L.), namun sampai sekarang belum ada penelitian tentang khasiat Ekstrak kayu secang (Caesalpinia sappan L.) terhadap Staphylococcus aureus dari isolat pus pasien maupun isolat laboratorium kaitannya dengan resitensi antibiotik. Penelitian ini ingin mengetahui aktivitas antibakteri ekstrak etanolik kayu secang (Caesalpinia sappan L.) terhadap Staphylococcus aureus yang bersumber dari isolat laboratorium dan pus pasien Rumah Sakit di Surakarta untuk mengetahui apakah ada perbedaan aktivitas antibakteri ekstrak etanolik kayu secang (Caesalpinia sappan L.) terhadap kedua sumber sampel tersebut.

\section{METODE PENELITIAN}

\section{Alat dan Bahan Penelitian}

Alat yang digunakan adalah oven, ayakan 40 mesh, neraca analitik, klem, statif, rangkaian alat Bidwell-sterling, ratory evaporator, pembakar spirtus, jarum oshe, autoclave, inkubator, kapas lidi steril, mikroskop.

Bahan yang digunakan adalah ekstrak etanolik kayu secang, media NA (Nutrient Agar), media BHI (Brain Heart Infusion), media VJA (Vogel Johnson Agar), media MHA (Muller Hinton Agar), kalium telurit, larutan $\mathrm{H}_{2} \mathrm{O}_{2} 3 \%$, plasma citrat, xylen, etanol 70\%, DMSO 2\%, spirtus, minyak imersi, cat Gram A (kristal violet), Gram B (lugol iodine), Gram C (alkohol-aceton), Gram D (safranin), Ciprofloxacin, larutan pengencer berupa $\mathrm{NaCl}$ 0,9\%.

Penelitian ini menggunakan serutan kayu secang (Caesalpinia sappan L.) yang berasal dari Pedagang di Pasar Gede Surakarta, Jawa Tengah. Bakteri uji yang digunakan adalah Staphylococcus aureus ATCC 25923 dari isolat Laboratorium Mikrobiologi Universitas Setia Budi Surakarta dan isolat pus pasien Rumah Sakit di Surakarta.

\section{Prosedur Penelitian}

\section{Pembuatan Ekstrak Etanolik Kayu} Secang (Caesalpinia sappan L.)

Serbuk kayu secang diekstraksi dengan metode maserasi dengan perbandingan serbuk dan pelarut yaitu 1:10. Serbuk kayu secang ditimbang sebanyak 300 gram kemudian dimasukkan dalam botol reagen coklat dan ditambah $3000 \mathrm{ml}$ etanol 70\%. Botol ditutup lalu ekstrak direndam selama 5 hari dengan beberapa kali dihomogenkan. Maserat kemudian disaring dengan menggunakan kain flanel dan kertas saring. Filtrat yang didapatkan kemudian dipekatkan dengan alat ratory evaporator hingga terbentuk ekstrak kental.

\section{Uji Fitokimia Ekstrak Etanolik Kayu Secang (Caesalpinia sappan L.)}

Uji fitokimia ekstrak etanolik kayu secang menggunakan reaksi tabung. Golongan senyawa yang diuji meliputi flavonoid, saponin, alkaloid, tanin dan fenolik.

Identifikasi flavonoid diuji dengan cara ekstrak sebanyak $1 \mathrm{ml}$ ditambahkan 
serbuk magnesium (Mg) secukupnya kemudian ditambah 10 tetes larutan $\mathrm{HCl}$ pekat. Diamati terbentuknya warna hitam kemerahan, kuning atau jingga indikasi adanya flavonoid (Endarini, 2016).

Identifikasi saponin diuji dengan cara ekstrak ditambah $10 \mathrm{ml}$ air panas lalu ditambah HCL 1\% kemudian dikocok kuat selama 10 detik. Diamati terbentuknya busa stabil indikasi adanya saponin (Harborne, 1987).

Identifikasi tanin diuji dengan cara ekstrak sebanyak $1 \mathrm{ml}$ ditambahkan 2-3 tetes larutan $\mathrm{FeCl}_{3} \quad 1 \%$ lalu diamati terbentuknya warna hitam kebiruan atau hijau indikasi adanya tanin (Endarini, 2016). Identifikasi alkaloid diuji dengan cara ekstrak ditambah $2 \mathrm{ml}$ larutan $\mathrm{HCl}$ lalu dipanaskan selama 5 menit dan disaring. Filtrat ditambah 2-3 tetes reagen Dragendorff. Hasil positif ditunjukkan dengan terbentuknya endapan jingga (Endarini, 2016). Identifikasi fenolik diuji dengan caraekstrak ditambah 2-3 tetes $\mathrm{FeCl}_{3} 1 \%$ kemudian diamati reaksi warna yang terbentuk. Hasil positif ditunjukkan dengan terbentuknya warna hijau, merah, ungu, biru, atau hitam yang kuat (Harborne, 1987).

\section{Identifikasi Sampel Bakteri}

1. Isolasi pada Media VJA (Vogel Johnson Agar)

Sampel Staphylococcus aureuskultur murni Laboratorium dan isolat pus pasien diisolasi pada media VJA yang telah ditetesi kalium telurit $1 \%$ sebanyak 4 tetes lalu diinkubasi pada suhu $37^{\circ} \mathrm{C}$ selama 24-48 jam.

\section{Pengecatan Gram}

Koloni bakteri yang tumbuh pada media VJA kemudian dibuat preparat di atas objek glass dan dilakukan pengecatan Gram. Preparat yang telah mongering kemudian diamati dibawah mikroskop dengan perbesaran 1000 kali.

3. Uji Katalase

Koloni yang tumbuh berwarna hitam pada media VJA diambil menggunakan jarum oshe dan diletakkan di atas obyek glass lalu diteteskan larutan $\mathrm{H}_{2} \mathrm{O}_{2} \quad 3 \%$. Hasil yang positif ditunjukkan dengan terbentuknya gelembung-gelembung gas (Cappucino dan Sherman, 2013).

4. Uji Koagulase

Plasma dipipet sebanyak $200 \mu$ l lalu dimasukkan ke dalam tabung reaksi steril. Biakan Staphylococcus aureus ditambahkan sebanyak 3-4 koloni dan dicampurkan dengan hati-hati. Hasil positif apabila terbentuk gumpalan atau endapan di dasar tabung (Dewi, 2013).

\section{Pembuatan Suspensi Bakteri}

Koloni pada media Vogel Johnson Agar (VJA) kemudian diinokulasikan ke media Brain Hearth Infusion (BHI). Tingkat kekeruhan disetarakan dengan Standart Mc. Farland 1,5 x $10^{8} \mathrm{cfu} / \mathrm{ml}$.

\section{Uji Aktivitas Antibakteri Metode Difusi Kirby Bauer}

Kertas cakram direndam dalam ekstrak etanolik kayu secang konsentrasi $25 \%, 50 \%, 75 \%$ dan $100 \%$ selama 2-4 jam kemudian di letakkan di atas media MHA yang telah diinokulasikan suspensi bakteri Staphylococcus aureuskultur murni Laboratorium dan isolat pus pasien Rumah Sakit lalu diinkubasi pada suhu $37^{\circ} \mathrm{C}$ selama 24 jam. Percobaan dilakukan sebanyak 3 kali pengulangan. Hasil zona hambat ekstral etanolik kayu secang yang 
terbentuk disekitar kertas cakram diukur diameternya dengan penggaris. Ciprofloxacin digunakan sebagai kontrol positif dan DMSO 2\% digunakan sebagai kontrol negatif.

\section{Uji Aktivitas Antibakteri Metode Dilusi}

Pengujian pertama aktivitas antibakteri metode dilusi menggunakan konsentrasi ekstrak etanolik kayu secang $100 \%, 90 \%, 80 \%, 70 \%, 60 \%, 50 \%, 40 \%$, $30 \%, 20 \%$, dan $10 \%$ dengan pengencer berupa $\mathrm{NaCl} 0,9 \%$. Kemudian dilanjutkan menggunakan konsentrasi ekstrak 9\%, $8 \%$, $7 \%, 6 \%, 5 \%, 4 \%, 3 \%, 2 \%$, dan $1 \%$. Kontrol positif berupa suspensi bakteri Staphylococcus aureus kultur murni Laboratorium dan isolat pus pasien Rumah Sakit sedangkan kontrol negatif berupa ekstrak etanolik kayu secang konsentrasi $100 \%$ untuk pengujian pertama dan konsentrasi $10 \%$ untuk pengujian kedua. Tabung-tabung tersebut kemudian diinkubasi pada suhu $37^{\circ} \mathrm{C}$ selama 24 jam lalu digores pada media VJA. Nilai KBM ditentukan setelah media VJA diinkubasi pada suhu $37^{\circ} \mathrm{C}$ selama $24-48$ jam. Nilai KHM pada penelitian ini tidak dapat ditentukan dikarenakan ekstrak kayu secang yang berwarna merah orange sehingga pada tabung tidak dapat diamati kekeruhannya.

\section{Analisis Data}

Data hasil uji difusi dilakukan uji statistika menggunakan uji Shapiro-Wilk dan dilanjutkan dengan uji parametrik berupa uji Two Way Anova.

\section{HASIL DAN PEMBAHASAN} Hasil Uji Fitokimia

Hasil uji fitokimia ekstrak etanolik kayu secang menunjukkan hasil positif mengandung senyawa saponin, flavonoid, tanin dan fenolik, sedangkan senyawa alkaloid menunjukkan hasil negatif. Hasil tersebut berbeda dengan hasil penelitian Kusmiati et al (2014) yang menyebutkan bahwa serbuk kayu secang mengandung senyawa alkaloid. Perbedaan hasil ini kemungkinan dapat disebabkan karena adanya perbedaan proses pengeringan, pengayakan, metode ekstraksi, pelarut dan metode identifikasi kandungan dalam ekstrak secang.

\section{Hasil Identifikasi Staphylococcus aureus}

1. Isolasi pada Media VJA (Vogel Johnson Agar)

Staphylococcus aureuskultur laboratorium dan isolat pus pasien pada media VJA tumbuh dengan ciri koloni bulat berwarna hitam, cembung dan disekitar koloni berwarna kuning.

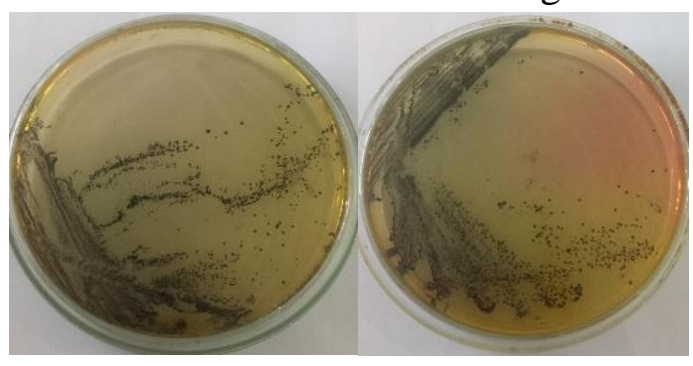

(a)

(b)

Gambar 1. Hasil pertumbuhan koloni Staphylococcus aureus pada media VJA (a) Sampel Laboratorium (b) Sampel Rumah Sakit

\section{Pengecatan Gram}

Staphylococcus aureus kultur murni dan isolat pus pasienpada pengecatan Gram bersifat Gram positif berwarna ungu, berbentuk bulat dan terlihat tersusun sendiri atau bergerombol. 


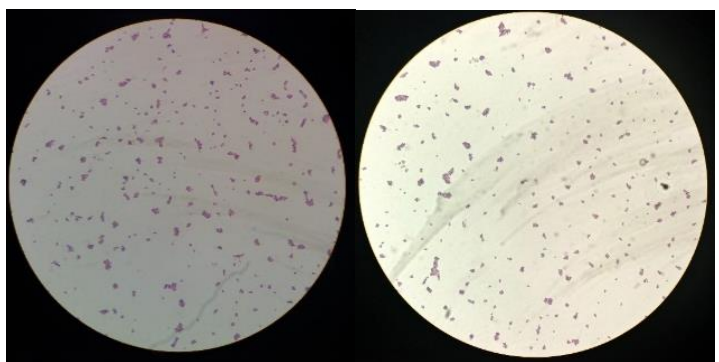

(a)

(b)

Gambar 2. Hasil pengecatan Gram

(a) Sampel Laboratorium (b) Sampel Rumah Sakit

\section{Uji Katalase}

Staphylococcus aureuskultur murni dan isolat pus pasien pada uji katalase menghasilkan gelembung-gelembung gas yang menandakan bakteri tersebut menghasilkan enzim katalase.

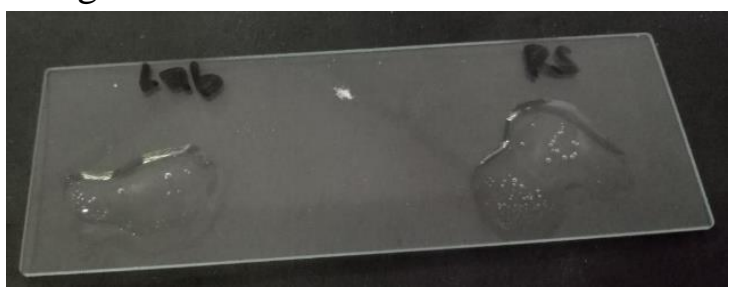

(a)

(b)

Gambar 3. Hasil uji katalase (a) Sampel Laboratorium (b) Sampel Rumah Sakit

\section{Uji Koagulase}

Staphylococcus aureuskultur murni dan isolat pus pasien pada uji koagulase menunjukkan adanya endapan di dasar tabung yang menandakan enzim koagulase positif.

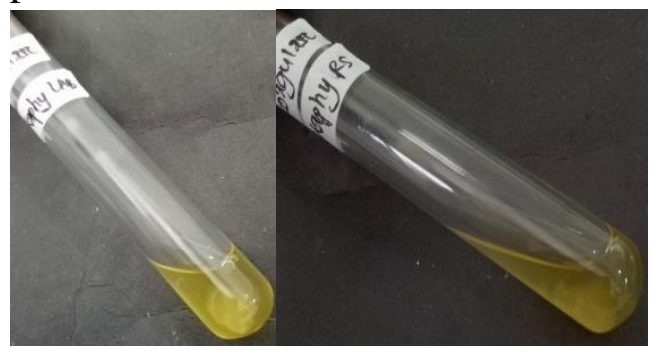

(a)

(b)

\section{Hasil Uji Aktivitas Antibakteri Metode Difusi Cakram}

\section{Sampel Kultur Murni Laboratorium}

Hasil uji aktivitas antibakteri ekstrak etanolik kayu secang terhadap Staphylococcus aureus dari kultur murni Laboratorium dapat dilihat pada Gambar 5 dan Tabel 1.

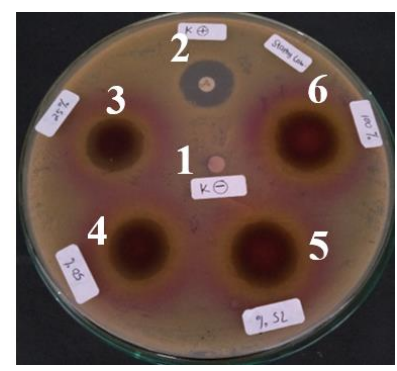

Gambar 5. Hasil uji difusi cakram ekstrak etanolik kayu secang terhadap Staphylococcus aureuskultur murni Laboratorium

Keterangan:

$1:$ Kontrol negatif (DMSO 2\%)

2: Kontrol positif (Ciprofloxacin)

3 : Ekstrak konsentrasi $25 \%$

4 : Ekstrak konsentrasi $50 \%$

5 : Ekstrak konsentrasi $75 \%$

6 : Ekstrak konsentrasi 100\%

Tabel 1. Hasil Uji Aktivitas Antibakteri Staphylococcus aureus Kultur Murni

\begin{tabular}{ccccc}
\hline & \multicolumn{3}{c}{ Diameter } & Rata-rata \\
Zona Hambat & $\begin{array}{c}\text { Diameter } \\
\text { Zona } \\
\text { Hambat } \\
(\mathbf{m m})\end{array}$ \\
\hline Kontrol (+) & 36 & 31 & 21 & 29.3 \\
\hline $\begin{array}{c}\text { Konsentrasi } \\
\text { 25\% }\end{array}$ & 30 & 31 & 22 & 27.7 \\
\hline $\begin{array}{c}\text { Konsentrasi } \\
50 \%\end{array}$ & 33 & 32 & 22 & 29 \\
\hline $\begin{array}{c}\text { Konsentrasi } \\
75 \%\end{array}$ & 29 & 34 & 23 & 28.7 \\
\hline $\begin{array}{c}\text { Konsentrasi } \\
100 \%\end{array}$ & 34 & 36 & 25 & 31.7 \\
\hline Kontrol (-) & 0 & 0 & 0 & 0 \\
\hline
\end{tabular}

Gambar 4. Hasil uji koagulase (a) Sampel Laboratorium (b) Sampel Rumah Sakit 
Berdasarkan rerata diameter zona hambat yang diperoleh dapat dinyatakan bahwa daya hambat yang dihasilkan oleh ekstrak etanolik kayu secang terhadap Staphylococcus aureus kultur murni Laboratorium pada semua konsentrasi yaitu konsentrasi 25\%, 50\%, 75\% dan $100 \%$ adalah sangat kuat. Rerata diameter zona hambat yang dihasilkan antibiotik Ciprofloxacin lebih kecil dibanding dengan rerata diameter zona hambat yang dihasilkan ekstrak etanolik kayu secang pada konsentrasi $100 \%$. Hal ini menunjukkan bahwa daya hambat ekstrak etanolik kayu secang konsentrasi 100\% terhadap Staphylococcus aureus kultur murni Laboratorium lebih kuat dibanding dengan daya hambat yang dihasilkan antibiotik Ciprofloxacin

2. Sampel Isolat Pus Pasien Rumah Sakit

Hasil uji aktivitas antibakteri ekstrak etanolik kayu secang terhadap Staphylococcus aureus dari isolat pus pasien dapat dilihat pada Gambar 6 dan Tabel 2.

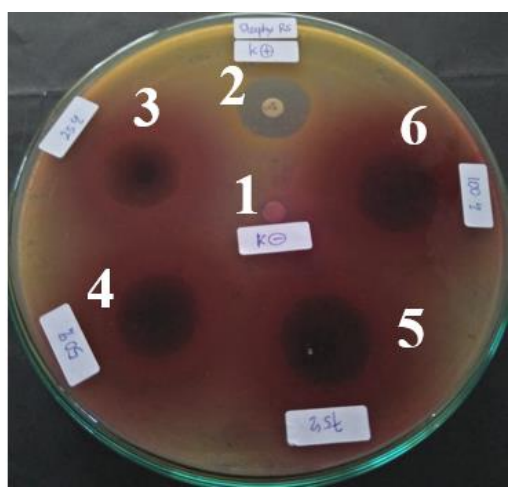

Gambar 6. Hasil uji difusi cakram ekstrak etanolik kayu secang terhadap Staphylococcus aureus isolat pus pasien Rumah Sakit

Keterangan:

$1:$ Kontrol negatif (DMSO 2\%)

2 : Kontrol positif (Ciprofloxacin)

3 : Ekstrak konsentrasi 25\%

4 : Ekstrak konsentrasi $50 \%$

5 : Ekstrak konsentrasi $75 \%$

6 : Ekstrak konsentrasi 100\%
Berdasarkan rerata diameter zona hambat yang diperoleh dapat dinyatakan bahwa daya hambat yang dihasilkan oleh ekstrak etanolik kayu secang terhadap Staphylococcus aureus isolat pus pasien Rumah Sakit pada semua konsentrasi yaitu konsentrasi 25\%, 50\%, 75\% dan 100\% adalah sangat kuat. Rerata diameter zona hambat yang dihasilkan antibiotik Ciprofloxacin adalah $24,7 \mathrm{~mm}$. Hal ini menunjukkan bahwa daya hambat yang dihasilkan ke empat konsentrasi ekstrak etanolik kayu secang terhadap Staphylococcus aureus isolat pus pasien Rumah Sakit lebih kuat dari antibiotik Ciprofloxacin.

Tabel 2. Hasil Uji Aktivitas Antibakteri Staphylococcus aureus pus pasien

\begin{tabular}{ccccc}
\hline & \multicolumn{2}{c}{ Diameter Zona } & $\begin{array}{c}\text { Rata- } \\
\text { Hambat }\end{array}$ \\
\cline { 2 - 5 } Jenis & R1 & R2 & R3 & $\begin{array}{c}\text { Zomater } \\
\text { Zoma } \\
\text { Hambat } \\
(\mathbf{m m})\end{array}$ \\
\hline Kontrol (+) & 27 & 25 & 22 & 24.7 \\
\hline $\begin{array}{c}\text { Konsentrasi } \\
25 \%\end{array}$ & 32 & 31 & 23 & 28.7 \\
\hline $\begin{array}{c}\text { Konsentrasi } \\
50 \%\end{array}$ & 35 & 31 & 25 & 30.3 \\
\hline $\begin{array}{c}\text { Konsentrasi } \\
75 \%\end{array}$ & 35 & 33 & 23 & 30.3 \\
\hline $\begin{array}{c}\text { Konsentrasi } \\
100 \%\end{array}$ & 37 & 34 & 26 & 32.3 \\
\hline Kontrol (-) & 0 & 0 & 0 & 0 \\
\hline
\end{tabular}

\section{Hasil Uji Aktivitas Antibakteri Metode Dilusi}

1. Sampel isolat Laboratorium

Hasil uji dilusi ekstrak etanolik kayu secang terhadap Staphylococcus aureus isolat Laboratoriumdapat dilihat pada Gambar 7 dan Tabel 3. 


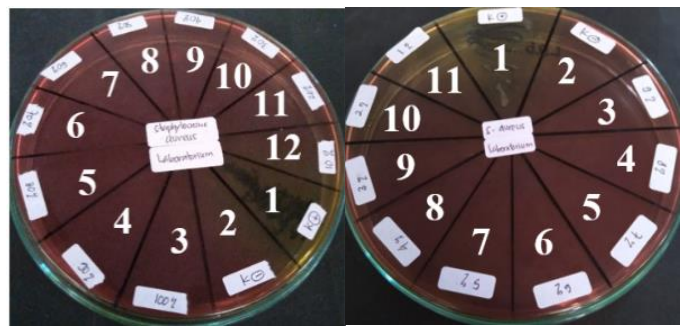

(a)

(b)

Gambar 7. Hasil uji dilusi ekstrak etanolik kayu secang terhadap Staphylococcus aureuskultur murni Laboratorium

Keterangan: (a) Ekstrak konsentrasi 100\% sampai 10\%: (1) Kontrol positif (2) Kontrol negatif, $(3,4,5,6,7,8,9,10,11,12)$ berturut turut Ekstrak konsentrasi 100\%, 90\%,80\%,70\%, $60 \%, 50 \%, 40 \%$, 30\%, 20\%, dan $10 \%$.

Keterangan (b) Ekstrak konsentrasi 9\% sampai 1\%: (1) : Kontrol positif(2) : Kontrol negatif, $(3,4,5,6,7,8,9,10,11,12)$ berturut turut ekstrak konsentrasi $9 \%, 8 \%, 7 \%, 6 \%, 5 \%, 4 \%, 3 \%, 2 \%$, dan $1 \%$.

Tabel 3. Hasil Uji Dilusi Ekstrak Etanolik Kayu Secang terhadap Staphylococcus aureus Kultur Murni Laboratorium

\begin{tabular}{cccc}
\hline Konsentrasi & Hasil & Konsentrasi & Hasil \\
\hline $\begin{array}{c}\text { Kontrol } \\
\text { negatif }\end{array}$ & - & $\begin{array}{c}\text { Kontrol } \\
\text { negatif }\end{array}$ & - \\
\hline $100 \%$ & - & $9 \%$ & - \\
\hline $90 \%$ & - & $8 \%$ & - \\
\hline $80 \%$ & - & $7 \%$ & - \\
\hline $70 \%$ & - & $6 \%$ & - \\
\hline $60 \%$ & - & $5 \%$ & - \\
\hline $50 \%$ & - & $4 \%$ & - \\
\hline $40 \%$ & - & $3 \%$ & - \\
\hline $30 \%$ & - & $2 \%$ & + \\
\hline $20 \%$ & - & $1 \%$ & + \\
\hline $10 \%$ & - & $\begin{array}{c}\text { Kontrol } \\
\text { positif }\end{array}$ & + \\
\hline Kontrol & + & & \\
\hline
\end{tabular}

Keterangan:

Negatif (-) $\rightarrow$ tidak ada pertumbuhan bakteri Positif $(+) \rightarrow$ ada pertumbuhan bakteri

Hasil uji dilusi ekstrak etanolik kayu secang terhadap Staphylococcus aureus kultur murni terdapat pertumbuhan koloni pada media VJA pada konsentrasi ekstrak $1 \%$ dan $2 \%$ sehingga nilai KBMnya adalah pada konsentrasi $3 \%$.

\section{Sampel Isolat Pus Pasien Rumah Sakit}

Hasil uji dilusi ekstrak etanolik kayu secang terhadap Staphylococcus aureusisolat pus pasien Rumah Sakitdapat dilihat pada Gambar 8 dan Tabel 4.

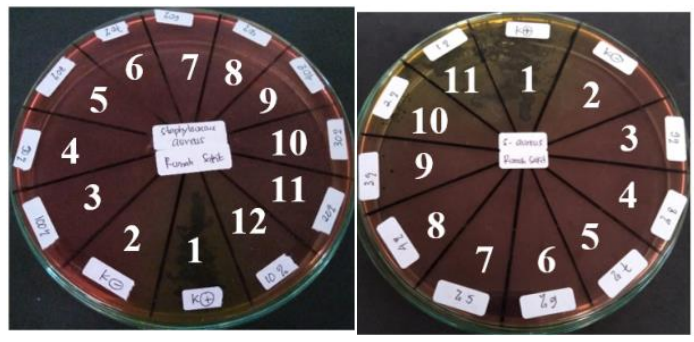

(a)

(b)

Gambar 8. Hasil uji dilusi ekstrak etanolik kayu secang terhadap Staphylococcus aureus isolat pus pasien Rumah Sakit

Keterangan (a) Ekstrak konsentrasi 100\% sampai 10\%: (1) Kontrol positif (2) Kontrol negatif, $(3,4,5,6,7,8,9,10,11,12)$ berturut turut Ekstrak konsentrasi 100\%, 90\%,80\%,70\%, $60 \%, 50 \%, 40 \%, 30 \%, 20 \%$, dan $10 \%$. Keterangan (b) Ekstrak konsentrasi 9\% sampai 1\%: (1) : Kontrol positif (2) : Kontrol negatif, $(3,4,5,6,7,8,9,10,11,12)$ berturut turut ekstrak konsentrasi $9 \%, 8 \%, 7 \%, 6 \%, 5 \%, 4 \%, 3 \%, 2 \%$, dan $1 \%$.

Hasil uji dilusi ekstrak etanolik kayu secang terhadap Staphylococcus aureus isolat pus pasien terdapat pertumbuhan koloni pada media VJA pada 
konsentrasi ekstrak 1\%, 2\% dan $3 \%$ sehingga nilai KBMnya adalah pada konsentrasi $4 \%$.

Staphylococcus aureus merupakan bakteri gram positif berdiameter $0,7-1,2$ $\mu \mathrm{m}$, berbentuk bulat, tersusun secara tidak teratur menyerupai buah anggur, tidak bergerak, bersifat fakultatif anaerob, dan tidak membentuk spora. Staphylococcus aureus yang patogen bersifat invasif, membentuk koagulase, mencairkan gelatin, menyebabkan hemolisis, membentuk pigmen kuning emas, dan mampu memfermentasi manitol (Kuswiyanto, 2018). Staphylococcus aureus paling sering menyebabkan sakit pada kulit dan jaringan superfisial, seperti luka bakar, pustula, koreng, abses, dan infeksi karena kecelakaan dan infeksi sesudah menjalani operasi (Iskamto, 2009). Patogenitas bakteri ini sering dihubungkan dengan infeksi luka bernanah, yang merupakan penyebab utama kasus piemia. Infeksi serius dari bakteri Staphylococcus aureus dapat berupa pneumonia, mastitis, meningitis, dan infeksi saluran kemih (Kuswiyanto, 2018).

Tabel 4. Hasil Uji Dilusi Ekstrak Etanolik Kayu Secang terhadap Staphylococcus aureus Isolat Pus Pasien Rumah Sakit

\begin{tabular}{cccc}
\hline Konsentrasi & Hasil & Konsentrasi & Hasil \\
\hline $\begin{array}{c}\text { Kontrol } \\
\text { negatif }\end{array}$ & - & $\begin{array}{c}\text { Kontrol } \\
\text { negatif }\end{array}$ & - \\
\hline $100 \%$ & - & $9 \%$ & - \\
\hline $90 \%$ & - & $8 \%$ & - \\
\hline $80 \%$ & - & $7 \%$ & - \\
\hline $70 \%$ & - & $6 \%$ & - \\
\hline $60 \%$ & - & $5 \%$ & - \\
\hline
\end{tabular}

\begin{tabular}{cccc}
\hline $50 \%$ & - & $4 \%$ & - \\
\hline $40 \%$ & - & $3 \%$ & + \\
\hline $30 \%$ & - & $2 \%$ & + \\
\hline $20 \%$ & - & $1 \%$ & + \\
\hline $10 \%$ & - & $\begin{array}{r}\text { Kontrol } \\
\text { positif }\end{array}$ & + \\
\hline
\end{tabular}

\begin{tabular}{c}
$\begin{array}{c}\text { Kontrol } \\
\text { positif }\end{array}$ \\
\hline
\end{tabular}

Keterangan:

Negatif $(-) \rightarrow$ tidak ada pertumbuhan bakteri Positif $(+) \rightarrow$ ada pertumbuhan bakteri

Berdasarkan hasil penelitian yang telah dilakukan menunjukkan bahwa ekstrak etanolik kayu secang (Caesalpinia sappan L.) memiliki aktivitas antibakteri terhadap Staphylococcus aureus dengan melihat adanya zona hambat yang terbentuk pada uji difusi. Pengujian ekstrak etanolik kayu secang menunjukkan rerata zona hambat terbesar terhadap Staphylococcus aureus kultur murni pada konsentrasi $100 \%$ yaitu sebesar 31,7 mm, sedangkan pada Staphylococcus aureus isolat pus pasien pada konsentrasi $100 \%$ yaitu sebesar 32,3 mm. Hasil difusi ekstrak etanolik kayu secang terhadap kedua jenis bakteri menunjukkan daya hambat yang lebih besar dari daya hambat kontrol positif antibiotik Ciprofloxacin, yang menandakan bahwa ekstrak kayu secang sangat baik dalam menghambat kedua jenis bakteri tersebut terutama yang bersumber dari isolat pus pasien Rumah Sakit. Hal ini sejalan dengan penelitian Silviani dan Handayani (2017) yang menyimpulkan bahwa kombinasi rebusan kayu secang (Caesalpinia sappan L.) dan madu mampu menghambat pertumbuhan bakteri Staphylococcus aureus dengan kombinasi optimal 6:2. 
Hasil uji dilusi menunjukkan ekstrak etanolik kayu secang konsentrasi $100 \%, 90 \%, 80 \%, 70 \%, 60 \%, 50 \%, 40 \%$, $30 \%$, 20\%, dan $10 \%$ terhadap Staphylococcus aureus kultur murni Laboratorium dan isolat pus pasien Rumah Sakit pada media VJA tidak ditemukan pertumbuhan koloni bakteri, hal ini berarti bahwa pada konsentrasi-konsentrasi tersebut ekstrak etanolik kayu secang masih mampu membunuh Staphylococcus aureus kultur murni dan isolat pus pasien. Berdasarkan hasil uji dilusi diatas diketahui bahwa Staphylococcus aureus isolat pus pasien memiliki nilai KBM yang lebih tinggi dibanding dengan nilai KBM pada Staphylococcus aureus kultur murni, namun perbedaan nilai KBM dari kedua jenis bakteri tersebut tidaklah berbeda jauh sehingga dapat dikatakan bahwa kemampuan ekstrak etanolik kayu secang dalam menghambat pertumbuhan Staphylococcus aureus kultur murni dan isolat pus pasien adalah sama baiknya. Menurut penelitian Sunraini dan Enlita (2015) ekstrak kayu secang (Caesalpinia sappan L.) dengan metode dilusi juga mampu menghambat pertumbuhan jamur Candida albicans dengan memiliki nilai KBM pada konsentrasi $80 \%$.

Data hasil uji difusi dilakukan uji statistika menggunakan uji ShapiroWilksebagai uji normalitas kemudian dilanjutkan dengan uji parametrik berupa uji Two Way Anova dan dilanjutkan dengan uji Post Hoc dan uji One Way Anova. Uji statistika ini dilakukan untuk mengetahui konsentrasi ektrak etanolik kayu secang yang paling efektif dalam menghambat pertumbuhan Staphylococcus aureus kultur murni dan isolat pus pasien serta untuk mengetahui dari kedua jenis bakteri tersebut manakah yang lebih sensitif terhadap ekstrak. Hasil uji normalitas Shapiro-wilk menunjukkan nilai signifikansi kedua data uji difusi adalah lebih besar dari $0,05\left(\mathrm{H}_{\mathrm{o}}\right.$ diterima $)$ yang berarti bahwa data terdistribusi normal. Hasil uji parametrik menunjukkan konsentrasi ekstrak etanolik kayu secang yang paling efektif dalam menghambat pertumbuhan Staphylococcus aureus kultur murni dan isolat pus pasien adalah konsentrasi $25 \%$ serta aktivitas antibakteri ekstrak etanolik kayu secang konsentrasi $25 \%$ terhadap Staphylococcus aureus kultur murni dan isolat pus pasien adalah sama.

Ekstrak etanolik kayu secang mempunyai aktivitas antibakteri karena mempunyai senyawa metabolit sekunder yaitu flavonoid, fenolik, tanin dan saponin. Flavonoid sebagai antibakteri dapat menimbulkan denaturasi protein yang terdapat pada dinding sel sehingga dapat merusak susunan dan merubah mekanisme permeabilitas dari mikrosom, lisosom dan dinding sel (Erianti et al, 2015). Fenolik pada kayu secang menghambat pertumbuhan bakteri dengan cara menginaktivasi enzim seluler yang dipengaruhi oleh kemampuannya dalam melakukan penetrasi ke dalam sel atau disebabkan oleh adanya perubahan permeabilitas membran sel akibat bergabungnya senyawa antibakteri dengan membran sel, hal ini menyebabkan kerusakan fungsi integritas membran sitoplasma, makromolekul dan ion sel keluar, kemudian disorientasi komponenkomponen lipoprotein serta mencegah berfungsinya membran sebagai pelindung terhadap tekanan osmotik (Jawetz, 2001). Tanin mempunyai kemampuan sebagai antimikroba diduga karena tanin akan membentuk kompleks dengan enzim 
ekstraseluler yang dihasilkan oleh patogen atau dengan mengganggu proses metabolisme patogen tersebut (Cordoves et al, 2001). Saponin mempunyai kemampuan sebagai antibakteri dengan cara menurunkan tegangan permukaan sehingga mengakibatkan naiknya permeabilitas atau kebocoran sel dan mengakibatkan senyawa intraseluler akan keluar (Nuria et al, 2009). Saponin dapat berdifusi melalui membran luar dan dinding sel yang rentan, lalu mengikat membran sitoplasma serta mengganggu dan mengurangi kestabilannya. Hal ini menyebabkan sitoplasma bocor keluar sel yang mengakibatkan kematian sel. Agen antimikroba yang mengganggu membran sitoplasma bersifat bakteriosida (Lorent et al, 2014).

Penelitian ini bakteri uji pada penelitian ini hanya menggunakan Staphylococcus aureus dari 1 sumber sampel pus dan belum mewakili Staphylococcus aureus dari isolat pus yang mengalami resistensi sehingga perlu dilakukan penelitian lebih lanjut uji aktivitas antibakteri ekstrak etanolik kayu secang terhadap bakteri MethicillinResistant Staphylococcus aureus (MRSA). Hasil yang diperoleh pada penelitian ini menunjukkan ekstrak etanolik kayu secang memiliki kemampuan sebagai antibakteri sehingga perlu dilakukan penelitian lebih lanjut terhadap ekstrak etanolik kayu secang (Caesalpinia sappan L.) untuk dikembangkan menjadi antiseptik.

\section{KESIMPULAN}

Berdasarkan penelitian yang telah dilakukan, maka dapat disimpulkan bahwa ekstrak etanolik kayu secang (Caesalpinia sappan L.) mempunyai aktivitas antibakteri terhadap Staphylococcus aureus.Konsentrasi ekstrak etanolik kayu secang (Caesalpinia sappan L.) yang paling efektif dalam menghambat Staphylococcus aureusisolat Laboratorium dan isolat pus pasien Rumah Sakit adalah pada konsentrasi 25\%. Nilai KBM ekstrak etanolik kayu secang (Caesalpinia sappan L.) terhadap Staphylococcus aureusisolat Laboratorium adalah konsentrasi 3\% dan Staphylococcus aureus isolat pus pasien Rumah Sakit adalah konsentrasi $4 \%$. Bakteri Staphylococcus aureusisolate Laboratorium dan isolat pus pasien Rumah Sakit memiliki kesensitifan yang sama terhadap ekstrak etanolik kayu secang (Caesalpinia sappan L.).

\section{DAFTAR PUSTAKA}

Artanti, D., dan Fatimah, S. 2017. Efektivitas Perasan Daun Keji Beling (Sericocalyx crispus Linn) Dalam Menghambat Pertumbuhan Staphylococcus aureus. The Journal Of Muhammadiyah Medical Laboratory Technologist, 2(1), 78-83. http://dx.doi.org/10.30651/jmlt.v1i1.1012

Cappucino, J.G. dan N. Sherman. 2013. Manual Laboratorium Mikrobiologi, terjemahan oleh Nur Miftahurahmah. Jakarta: Penerbit EGC.

Chen C. J., dan Huang,Y. C.. 2014. New epidemiology of Staphylococcus aureus infection in Asia. Clin Microbiol Infect, 20(7), 605-606.

https://doi.org/10.1111/1469-0691.12705

Cordoves, C.G., Bartolome B., Vieira W., dan Virador VM. 2001. Effects of Wine Phenolics and Sorghum Tanins on Tyrosinase Activity and Growth of Melanoma Cells. J Agric Food Chem, 49: 1620-1624. https://doi.org/10.1021/jf00111h

Dewi, A. 2013. Isolasi, Identifikasi dan Uji Sensitivitas Staphylococcus aureus terhadap Amoxcillin dari Sampel Susu Kambing Peranakan Ettawa (PE) Penderita Mastitis di Wilayah Girimulyo, Kulonprogo, Yogyakarta. Jurnal Sain Veteriner, 31(2): 138-150. $\quad$ http://ilib.ugm.ac.id/jurnal/detail.php?dataId=1249 
Endarini, L.H. 2016. Farmakognisi dan Fitokimia. Jakarta: Kemenkes RI.

Erianti, F., Marisa, D. dan Suharto, E. 2015. Potensi Antiinflamasi Jus Buah Belimbing (Averrhoa carambola L.) terhadap Denaturasi Protein In Vitro. Berkala Kedokteran, $\quad$ 11(1): 33-39. http://dx.doi.org/10.20527/jbk.v11i1.18

Harborne, J.B. 1987. Metode Fitokimia: Penuntun Cara Modern Menganalisis Tumbuhan, terbitan ke-2. Terjemahan Padmawinata, K. dan I. Soediro. Bandung: Penerbit ITB.

Iskamto, B. 2009. Bakteriologi Kesehatan. Surakarta: Yayasan Lingkungan Hijau.

Jawetz, E., J.J. Melnick and E.A. Adelberg. 2001. Mikrobiologi Kedokteran Buku 1. Bagian Mikrobiologi Fakultas Kedokteran Universitas Airlangga (Penerjemah). Jakarta: Salemba Medika.

Kumala, S., Yuliani, Tulus, D. 2009. Pengaruh Pemberian Rebusan Kayu Secang (Caesalpinia sappan L.) Terhadap Mencit Yang Diinfeksi Bakteri Escherichia coli. Jurnal Farmasi Indonesia, 4(4). https://doi.org/10.35617/jfi.v4i4.28

Kusmiati, Dameria, dan D. Priadi. 2014. Analisa Senyawa Aktif Ekstrak Kayu Secang (Caesalpinia sappan L.) yang Berpotensi sebagai Antimikroba. Seminar Nasional Teknologi Industri Hijau 1. Pusat Penelitian Bioteknologi LIPI-Institut Sains dan Teknologi Nasional. Hal 169-174. https://www.researchgate.net/publication/26 7627083 Analisa_Senyawa_Aktif_Ekstrak Kayu_Secang_Caesalpinia_sappan_L_yang Berpotensi_Sebagai_Antimikroba_Analysis _on_Compound_Extract_Secang_Wood_Ca esalpnia sappan_L_as_Potential_Antimicro $\underline{\text { bial }}$

Kusuma, I.W. 2007. Secang (Caesalpinia sappan L.): Telaah Aktifitas Biologis dan Potensi Pemanfaatannya. JRTI, 1(2), 14-23. doi: http://dx.doi.org/10.26578/jrti.v1i2.1398

Kuswiyanto. 2018. Bakteriologi 2: Buku Ajar Analis Kesehatan. Jakarta: Penerbit Buku Kedokteran EGC.

Lorent J.H., J. Quetin-Leclerq., and M.P. MingeotLeclerq. 2014. The Amphiphilic Nature of Saponins and their effects on artificial and biological membranes and potential consequences for red blood and cancer cells. Org Biomol Chem, 12(44): 88038822.

http://dx.doi.org/10.1039/C4OB01652A

Nurmala, I.G.N. Virgiandhy, Andriani, \& D.F. Liana. 2015. Resistensi dan Sensitivitas Bakteri terhadap Antibiotik di RSU dr. Soedarso Pontianak Tahun 2011-2013. eJournal Kedokteran Indonesia, 3(1), 2128. https://doi/org/10.23886ejki.3.4803

Nuria, M.C., A. Faizatun A., dan Sumantri. 2009. Uji Antibakteri Ekstrak Etanol Daun Jarak Pagar (Jatropha cuircas L) terhadap Bakteri Staphylococcus aureus ATCC 25923, Escherichia coli ATCC 25922 dan Salmonella typhi TCC 1408. Jurnal Ilmuilmu Pertanian, 5(2); 26-37. https://publikasiilmiah.unwahas.ac.id/inde x.php/Mediagro/article/view/559/680

Sa'diah, S., Darusman, L.K., Triwahyuni, W., dan Batubara, I. 2013. Efektivitas Krim Anti Jerawat Kayu Secang (Caesalpinia sappan) terhadap Propionibacterium acnes pada Kulit Kelinci. Jurnal Ilmu Kefarmasian Indonesia, 11(2): 175-181. http://jifi.farmasi.univpancasila.ac.id/index .php/jifi/article/download/214/151/

Singh S., M. Khare, R.K. Patidar, S. Bagde, K.N. Sahare, D. Dwevedi and V. Singh. 2013. Antibacterial Activities Against Pyogenic Pathogens. Int. Jour. of Pharmaceutical Sciences and Research. 4(8):2974-2979. Doi:

http://dx.doi.org/10.13040/IJPSR.09758232.4(8).2974-79

Silviani,Y. dan Handayani, S.2017. Pengaruh Variasi Kombinasi Rebusan Kayu Secang (caesalpinia sappan 1.) dan Madu Terhadap Pertumbuhan Staphylococcus aureus, 8(1), 42-46. http://jurnal.stikeskusumahusada.ac.id/ind ex.php/JK/article/download/210/208

Sunraini dan Enlita. 2015. Uji Potensi Ekstrak Kayu Secang (Caesalpinia sappan L.) dalam Menghambat Pertumbuhan Jamur Candida albicans. Jurnal Kesehatan Perintis, 47-56. https://www.neliti.com/id/publications/27 5139/uji-potensi-ekstrak-kayu-secangcaesalpina-sappan-li-dalam-menghambatpertumbuhan 